\title{
Histopathological alterations in the gills of banded gourami (Trichogaster fasciata) exposed to thiamethoxam
}

\author{
MD. MOHIBUL HASAN ${ }^{\mathrm{a}}$, MD. MAHMUDUL HASAN ${ }^{\mathrm{a}}$, MD. HELAL UDDIN ${ }^{\mathrm{a}}$, \\ KIZAR AHMED SUMON, AL-AMIN AND HARUNUR RASHID* \\ Department of Fisheries Management, Bangladesh Agricultural University, Mymensingh 2202, Bangladesh \\ aEqually contribution first authors; 'Corresponding Author: rashid@bau.edu.bd
}

\begin{abstract}
Thiamethoxam (THM) is a widely used agro-pesticide in Bangladesh, though European Union has banned this neonicotinoid insecticide due to its toxic effects on non-target organisms. A 60-day experiment was conducted to study the effect of sub-lethal concentrations of THM on gills of Banded Gourami Trichogaster fasciata. The experiment was conducted in 15 PVC tanks each containing 100L water. The 96-h LC50 value of THM was estimated as $161.06 \mathrm{mg} / \mathrm{L}$ for Banded Gourami. Based on estimated 96-h LC50 value, the experiment was carried out using a control ( $0 \mathrm{mg} / \mathrm{L}$ of THM) and five sub-lethal concentrations $(9.37,18.75,37.5,75$ and 150 $\mathrm{mg} / \mathrm{L}$ of THM in water) with three replications. For collection of gills, fishes were sampled on day-30 and day-60 of exposure to THM. Several histopathological changes were observed in the gill tissues of treated fishes viz. clubbing and reduction of gill filaments, telangiectasis of gill lamellae, haemorrhage and damage of gill raker. Water quality parameters (e.g. DO, pH and temperature) were recorded every 15 days interval. The DO levels were found to decrease significantly with increasing THM concentrations and time of exposure, whereas no noticeable changes were observed for $\mathrm{pH}$ and temperature. Therefore, neonicotinoid crop insecticide like THM is capable of damaging gill tissues of a small indigenous fish Banded Gourami.
\end{abstract}

Keywords: Banded Gourami, Trichogaster fasciata, thiamethoxam, histopathology, gill

\section{Introduction}

To meet the food demand for the increasing population, the government of Bangladesh has promoted the use of pesticides for producing more agricultural crops (Dasgupta et al. 2007). There was very minimum used of pesticides in Bangladesh before 1960s but abruptly increased about 7 times in amount from 1992 to 2010 (Ali et al. 2018). High Yielding Varieties (HYVs) are very much susceptible to pest for that reason the uses of pesticides are in increasing trends that also makes the environment polluted (Sumon et al. 2017). Pesticides eventually find their way into aquatic environments in many ways like spray drift, run off and leaching (Van den Brink 2013, Shahjahan et al. 2017). The release of this insecticide into the aquatic environment may have potential toxic effects on nontarget aquatic organisms like invertebrates (Rubach et al. 2011; 2012), and vertebrates (Manjunatha and Philip 2015, Sumon et al. 2016). Considering the importance of fish as food as well as having long life span and ability to respond against environmental xenobiotics treated as a good bio-indicator among vertebrates (Gupta et al. 2009; Narra et al. 2011, Correia et al. 2017).Fish may be directly affected by pesticides in many ways like changes in normal behavior e.g. feeding or swimming (Satyavardhan 2013, Ullah et al. 2014, Rani and Kumaraguru 2014), alteration of physiological functions such as changes in blood parameters (Blood glucose, WBCs, RBCs etc) as well as histo-architectural changes in some important internal organs like gills, liver, kidney, intestine etc. (Saeedi et al. 2012, Salam et al. 2015, Sharmin et al. 2015). THM is one of the mostly used neonicotinoid insecticide, which is commonly used for controlling insect in Bangladesh and causes severe

https://doi.org/10.52168/bjf.2021.33.06 
detrimental effects on the cellular level of respiration on aquatic organisms particularly fish (Betoulle et al. 2000).

Trichogasterfasciata, the Banded Gourami, has been used as a fish model for ecotoxicological studies (Sumon et al. 2017, 2019). This benthopelagic species of fish prefers weedy environments such as estuaries, ponds, large rivers, ditches, lakes etc. and native to Bangladesh, India, Myanmar, Nepal and Pakistan (Mitra et al. 2007). Short generation time and easy acclimatization and captive breeding in laboratory conditions have made this fish a popular model for aquatic stress studies (Sumon et al. 2017, Reza et al. 2020). Therefore, the present study was conducted to examine the effects of agro-pesticide THM on the gill tissues of Banded Gourami $T$. fasciata as a model animal.

\section{Materials and Methods}

Experimental fish and pesticide collection: Healthy and adult $T$. fasciata (body weight: $8.12 \pm$ $0.34 \mathrm{gm}$ and length: $9.2 \pm 0.8 \mathrm{~cm}$ ) were collected from natural waters in Mymensingh. Live $T$. fasciata $(n=250)$ were transported in well oxygenated polythene bags to the Wet Laboratory, Faculty of Fisheries, Bangladesh Agricultural University and were kept in cemented cistern with continuous water supply. They were reared under natural photoperiod for conditioning. Fish were fed with commercial fish feed at the rate of $3 \%$ body weight and twice daily. The fishes were conditioned for a period of 21 days. The pesticide THM 25WG (trade name: spike) was used for this experiment which was purchased from local retailer at Mymensingh town.

Experimental design: After 21 days, the acclimatized fish were exposed to five sub-lethal concentrations of THM $(9.37,18.75,37.5,75$ and $150 \mathrm{mg} / \mathrm{L})$ in three replicates based on previously estimated 96-h LC50 value, $161.06 \mathrm{mg} / \mathrm{L}$ for Banded Gourami. Fifteen 100-L plastic drums were used for fish holding, filled with dechlorinated water, equipped with aerators, released with 10 fish per drum, feeding daily at $3 \%$ of body weight and exposed for a period of 60 days. Unutilized feedstuffs and fecal wastes were cleaned dailyby siphoning. Water was exchanged fortnightly and the pesticide with respective doses was added accordingly. Fishes were sampled $(\mathrm{n}=3)$ on day 30 and day 60 to collect gills and fixed in Bouin's fluid for histopathological studies. Water quality parameters ( $\mathrm{DO}, \mathrm{pH}$, and temperature) were recorded weekly.

Histological procedures: Fixed gill tissues were dehydrated by passing through graded alcohol series, cleared by chloroform and embedded into molten paraffin. Embedded tissues were then sectioned at $5 \mu \mathrm{m}$ thickness using a microtome. The sections were placed on slides like ribbons, then stained with routine Haematoxylene-Eosin (H-E) protocols, followed by mounting with DPX and cover slip. The stained sections were observed under a microscope to detect the histopathological changes in gill tissues.

Statistical analysis: Values are expressed as means \pm standard deviation (SD). Data were analyzed by a one-way analysis of variance (ANOVA) followed by Tukey's post hoc test to assess statistically significant differences among different treatments. Statistical significance was set at $p<0.05$. Statistical analyses were performed using PASW Statistics 18.0 software (IBM SPSS Statistics, IBM, Chicago, USA). 


\section{Results}

Histopathological results indicated that gill tissue was the primary target affected by pesticide THM. The gills are key organs involved in nutrient uptake, ingestion and respiration. Various dose and duration-dependent histopathological alterations in Banded Gourami gills were observed exposed to THM (Figs. 1 and 2). The gills which extracted from the control fish showed almost no histopathological alterations during the experimental period. The control gills showed regular-shaped of gill arches (GA), gill rakers (GR), gill lamellae (GL) and gill filaments (GF) (Figs. 1A and 2A). The gills of exposed fishes were revealed different histopathological alterations like necrosis $(\mathrm{N})$, telangiectasis $(\mathrm{T})$, clubbing $(\mathrm{C})$ and reduction of gill filaments (RF) (Figs. 1B-E and 2B-E). A significant increase in histopathological alterations in gills was observed at all the pesticide treated groups on day-60 compared to day-30, respectively. There was a significant increase of histopathological alterations in the gills of Banded Gourami when exposed to $150 \mathrm{mg} / \mathrm{L}$ after both day-30 and day- 60 (Figs. 1F and 2F).
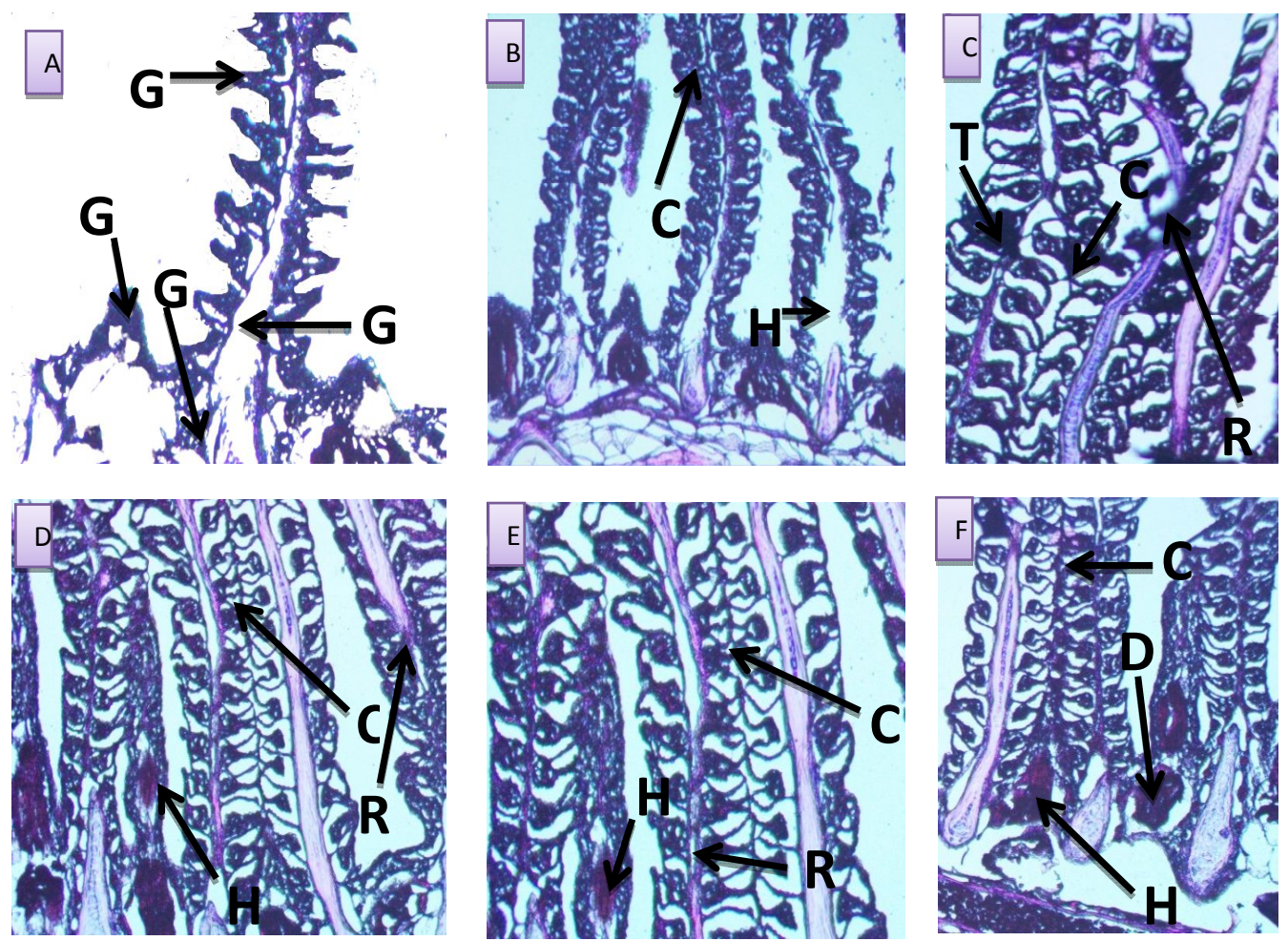

Fig. 1. Histopathological alterations observed in Banded Gourami T. fasciata exposed to thiamethoxam pesticide on 30 day, during the experimental period. (A) Almost normal structure of structure of gill arches (GA), gill rakers (GR), gill lamellae (GL) and gill filaments (GF) after 30 days exposure to $0 \mathrm{mg} / \mathrm{L}$ (control gill); (B) clubbing (C) and hypertrophy (HY) after 30 days exposure to $9.37 \mathrm{mg} / \mathrm{L}$; (C) clubbing (C), telangiectasis (T) and reduction of gill filaments (RF) after 30 days exposure to $18.75 \mathrm{mg} / \mathrm{L}$; (D) clubbing (C), haemorrhage (H) andreduction of gill filaments (RF) after 30 days exposure to $37.5 \mathrm{mg} / \mathrm{L}$; (E) clubbing $(\mathrm{C})$, haemorrhage $(\mathrm{H})$ and reduction of gill lamellae(RF) after 30 days exposure to $75 \mathrm{mg} / \mathrm{L}$; (F) clubbing (C), haemorrhage (H) and damage of gill raker (DR) after 30 days exposure to $150 \mathrm{mg} / \mathrm{L} ; \mathrm{H}$ and $\mathrm{E}$ stain $\times 400$. 

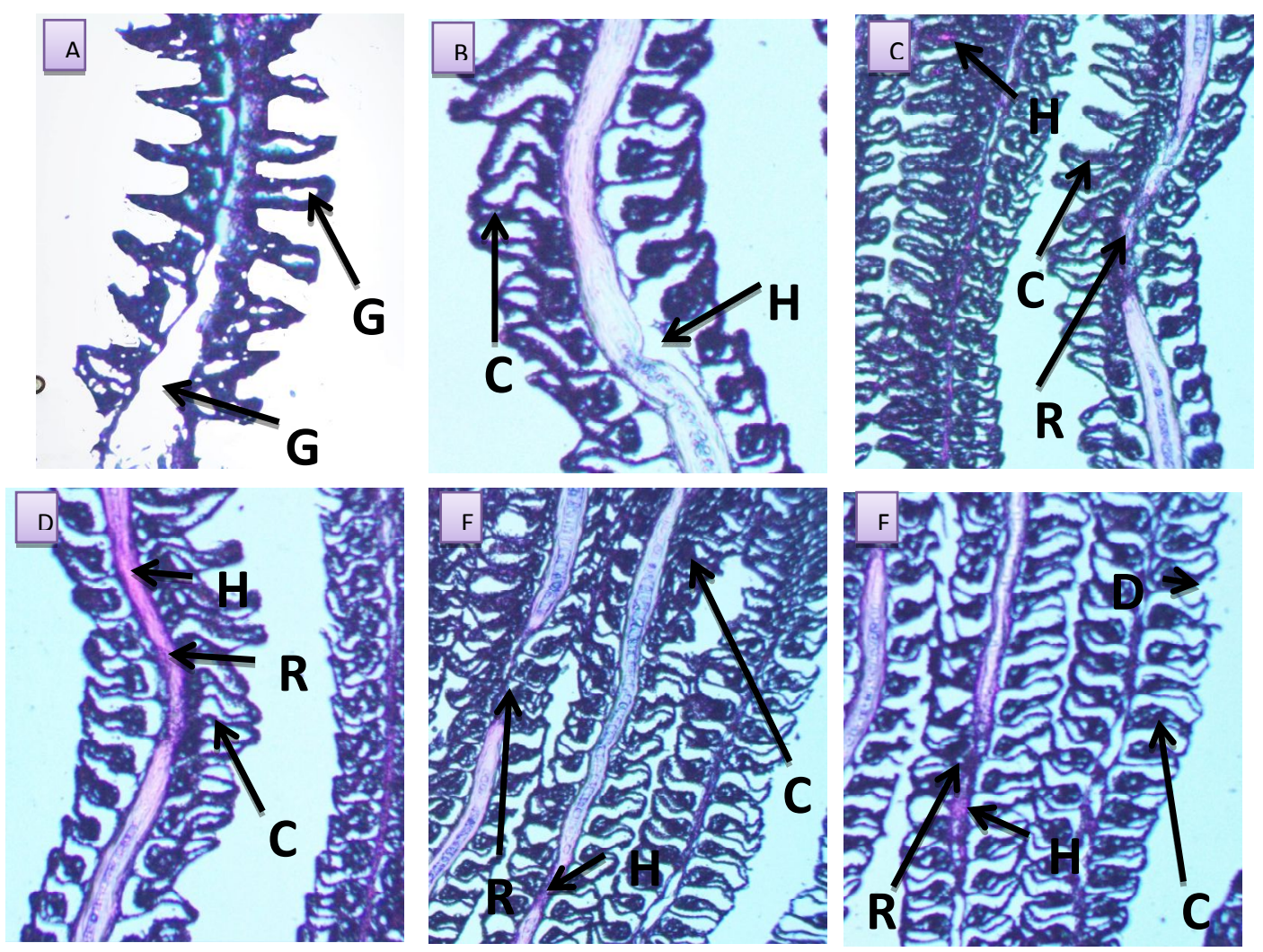

Fig. 2. Histopathological alterations observed in Banded Gourami T. fasciata exposed to thiamethoxam pesticide on 60 day, during the experimental period.(A) Almost normal structure of structure of gill lamellae (GL) and gill filaments (GF) after 60 days exposure to $0 \mathrm{mg} / \mathrm{L}$ (control gill); (B) clubbing (C) and hypertrophy (HY) after 60 days exposure to $9.375 \mathrm{mg} / \mathrm{L}$; (C) clubbing $(\mathrm{C})$, haemorrhage $(\mathrm{H})$ and reduction of gill filaments $(\mathrm{RF})$ after 60 days exposure to $18.75 \mathrm{mg} / \mathrm{L}$; (D) clubbing (C), reduction of gill filaments (RF) and haemorrhage (H) after 60 days exposure to $37.5 \mathrm{mg} / \mathrm{L}$; (E) clubbing $(\mathrm{C})$, reduction of gill filaments $(\mathrm{RF})$ and haemorrhage $(\mathrm{H})$ after 60 days exposure to 75 $\mathrm{mg} / \mathrm{L}$; (F) clubbing (C), damage of gill racker (DR), reduction of gill filaments (RF) and haemorrhage (H) after 60 days exposure to $150 \mathrm{mg} / \mathrm{L} ; \mathrm{H}$ and $\mathrm{E}$ stain $\times 400$.

The value of dissolved oxygen $(\mathrm{mg} / \mathrm{L}), \mathrm{pH}$, and temperature were presented in Table 1 . Dissolved oxygen $(\mathrm{mg} / \mathrm{L})$ values were found to be significantly reduced in all the pesticide treated groups compared the control group. The reduction of DO level at two higher pesticide exposed groups ( 75 and $150 \mathrm{mg} / \mathrm{L}$ ) were significantly significant. Whereas, the values of $\mathrm{pH}$ and temperature were almost unchanged throughout the study period (Table I). 
MD. MOHIBUL HASAN et al.

Table I. Water quality parameters (mean \pm SD) during the experimental period*

\begin{tabular}{l|c|c|c|c|c}
\hline Parameters & $\begin{array}{c}\text { Treatments } \\
(\mathrm{mg} / \mathrm{L})\end{array}$ & \multicolumn{4}{|c}{ Sampling Days } \\
\cline { 2 - 5 } & 0 & Day-15 & Day-30 & Day-45 & Day-60 \\
\hline \multirow{4}{*}{ DO (mg/L) } & $9.37 \pm 0.61^{\mathrm{b}}$ & $7.19 \pm 0.5^{\mathrm{c}}$ & $6.19 \pm 0.5^{\mathrm{b}}$ & $5.85 \pm 0.5^{\mathrm{a}}$ \\
\cline { 2 - 6 } & 18.75 & $7.19 \pm 0.5^{\mathrm{c}}$ & $6.35 \pm 0.35^{\mathrm{b}}$ & $5.33 \pm 0.65^{\mathrm{b}}$ & $4.68 \pm 0.41^{\mathrm{a}}$ \\
\cline { 2 - 6 } & 37.5 & $5.97 \pm 0.55^{\mathrm{b}}$ & $5.19 \pm 0.84^{\mathrm{b}}$ & $5.12 \pm 0.31^{\mathrm{b}}$ & $4.26 \pm 0.44^{\mathrm{a}}$ \\
\cline { 2 - 6 } & 75 & $5.12 \pm 0.61^{\mathrm{b}}$ & $4.40 \pm 0.45^{\mathrm{a}}$ & $4.55 \pm 0.69^{\mathrm{a}}$ & $4.76 \pm 0.65^{\mathrm{a}}$ \\
\cline { 2 - 6 } & 150 & $5.10 \pm 0.61^{\mathrm{c}}$ & $4.15 \pm 0.61^{\mathrm{b}}$ & $4.02 \pm 0.61^{\mathrm{b}}$ & $3.68 \pm 0.61^{\mathrm{a}}$ \\
\hline $\mathrm{P}^{\mathrm{H}}$ & 0 & $8.15 \pm 0.40$ & $7.5 \pm 0.40$ & $7.11 \pm 0.40$ & $7.29 \pm 0.40$ \\
\cline { 2 - 6 } & 9.37 & $7.64 \pm 0.20$ & $8.09 \pm 0.26$ & $7.44 \pm 0.42$ & $7.81 \pm 0.32$ \\
\cline { 2 - 6 } & 18.75 & $7.59 \pm 0.39$ & $7.66 \pm 0.21$ & $7.71 \pm 8.1$ & $7.77 \pm 0.17$ \\
\cline { 2 - 6 } & 37.5 & $7.57 \pm 0.32$ & $7.63 \pm 0.54$ & $7.69 \pm 7.63$ & $7.77 \pm 0.32$ \\
\cline { 2 - 6 } & 75 & $7.67 \pm 0.39$ & $7.75 \pm 0.22$ & $7.82 \pm 0.45$ & $7.88 \pm 0.22$ \\
\hline \multirow{5}{*}{ Temperature } & 150 & $7.17 \pm 0.39$ & $7.37 \pm 0.39$ & $7.43 \pm 0.39$ & $7.50 \pm 0.39$ \\
\cline { 2 - 6 }$\left({ }^{0} \mathrm{C}\right)$ & 0 & $28.18 \pm 7.20$ & $27.58 \pm 7.20$ & $28.38 \pm 7.20$ & $28.50 \pm 7.20$ \\
\cline { 2 - 6 } & 9.37 & $29.35 \pm 8.2$ & $29.22 \pm 8.2$ & $29.36 \pm 8.7$ & $29.82 \pm 6.59$ \\
\cline { 2 - 6 } & 18.75 & $29.12 \pm 7.31$ & $29.16 \pm 7.36$ & $29.21 \pm 0.62$ & $29.63 \pm 8.30$ \\
\cline { 2 - 6 } & 37.5 & $28.22 \pm 7.51$ & $29.36 \pm 7.15$ & $29.55 \pm 0.63$ & $29.87 \pm 7.57$ \\
\cline { 2 - 6 } & 75 & $29.36 \pm 7.65$ & $28.13 \pm 7.36$ & $29.54 \pm 8.20$ & $28.33 \pm 7.39$ \\
\hline
\end{tabular}

*Values with different alphabetical superscripts in a row differ significantly $(p<0.05)$ among different treatments.

All values were expressed as mean $\pm \mathrm{SD}$.

\section{Discussion}

Histopathological observation is a sensitive bio-monitoring tool to indicate the effect of toxicants on fish in pesticides polluted aquatic ecosystems (Marchand et al. 2009). Pesticides in polluted aquatic ecosystem are accumulated in fish mainly through metabolically active tissues such as gill, liver, kidney so on (Oruce and Usta 2007). Several histopathological changes were observed in the gill tissues of Banded Gourami, T. fasciata exposed to different sub-lethal concentrations of THM agro-pesticide for a period of 60 days. Histopathological alterations include clubbing, reduction of gill filaments, telangiectasis of gill lamellae, haemorrhage and damage of gill raker. Several investigators have reported that the histopathological changes were recorded in gills of different fish species exposed to various pesticides (Cengiz and Unlu 2002, 2003; Cengiz 2006). Mucus extrusion, lamellar swelling, fused and reduced microridges, were observed in bluegill sunfish, Lepomis macrochirus when exposed to different sub lethal concentrations of diazinon (Dutta et al. 1997). Histopathological effects of sub lethal concentrations of monocrotophos on the gills of Anabas testudineus was reported by Santhakumar et al. (2001). The observed histopathological changes were hemorrhage in the primary and secondary gill lamellae, degeneration and necrosis of epithelial cells, distortion of the secondary lamellae, and disruption of epithelial cells from pillar cells. Shorter gill lamellae, fusion, complete destruction of lamella, increased vacuolation, irregular appearance of gill lamellae were observed in guppy Poecilia reticulate exposed to chlorpyrifos (De Silva and Samayawardhena 2002). Degenerative changes in gill, such as intraepithelial edema in the secondary lamellae, thick coating of mucus covering the entire gill filaments and lamellae, erosion of secondary lamellae, thickening of lamellae, inflammation of epithelial cells, 
breakages in primary lamellae, degeneration of secondary lamellae, necrosis, rupture of epithelium were noticed during exposure of sub lethal concentrations of monocrotophos by Rao et al. (2005). Rao et al. (2005) observed uncontrolled regeneration of the primary lamellae and secondary lamellae, hypertrophy, hyperplasia, necrosis of the epithelial cells, epithelial lifting, and dilation of the blood sinuses of the secondary lamellae, lamellar aneurism, and hemorrhages in the gill of fish exposed to profenofos. Mukti et al. (2018) reported that female Banded Gourami exposed to different sub-lethal concentrations of chlorpyrifos resulted in hemorrhage, hypertrophy, necrosis, pyknosis, vacuums, splitted gill lamellae and missing of gill lamellae. All of the findings cited above are supportive to the present research. Among the water quality parameters, DO levels were found to be significantly low in all the treatments compared to control. Reduced DO levels in the higher pesticide concentrations made fishes become stressed and might have hampered the respiratory system resulting in the damaged of gills lamellae. On the other hand, no noticeable changes were observed between control and treatments in case of $\mathrm{pH}$ and temperature.

In conclusion, the results of the present study revealed that a neonicotinoid crop insecticide like thiamethoxam can cause histopathological alterations in gills of an indigenous freshwater fish Banded Gourami. Therefore, indiscriminate use of thiamethoxam to agriculture should be restricted.

Acknowledgement: This work was funded by the Ministry of Education, Bangladesh (Project no. LS2017536).

\section{Literature Cited}

Ali, M.H., K.A. Sumon, M. Sultana and H. Rashid, 2018. Toxicity of cypermethrin on the embryo and larvae of gangeticmystus, Mystuscavasius. Environ. Sci. Pollut. Res., 25: 3193-3199.

Betoulle, C., C. Duchiron and P. De Schaux, 2000.Lindane increase in vitro respiratory burst activity and intracellular calcium levels in rainbow trout (Oncorhynchusmykiss) head, kidney, phagocytes. $J$. Aquat. Toxicol., 48:211-221.

Cengiz, E.I., 2006.Gill and kidney histopathology in the freshwater fish Cyprinuscarpio after acute exposure to deltamethrin. Environ. Toxicol. Phar., 22:200-204.

Cengiz, E.I. and E. Unlu, 2002.Histopathologica changes in the gills of mosquitofish, Gambusiaaffinis exposed to endosulfan. B. Environ. Contam. Tox., 68:290-296.

Cengiz, E.I. and E. Unlu, 2003. Histopathology of gills in mosquitofish, Gambusiaaffinis after long-term exposure to sublethal concentrations of malathion. J. Environ. Sci. Health. B.,38: 581-589.

Correia, J.E., C.A. Christofoletti, A.C.C. Marcato, J.F.U. Marinho and C. Fontanetti, 2017.Histopathological analysis of tilapia gills (Oreochromisniloticus Linnaeus, 1758) exposed to sugarcane vinasse. Ecotoxicol. Environ. Safe., 135: 319-326.

Dasgupta, S., C. Meisner and M. Huq, 2007.A pinch or a pint: Evidence of pesticide overuse in Bangladesh. J. Agric. Econ., 58: 91-114.

De Silva, P.M.C.S. and L.A. Samayawardhena, 2002. Low concentrations of lorsban in water result in far reaching behavioral and histological effects in early life stages in guppy. Ecotoxicol. Environ. Safe, 53:248-254.

Dutta, H.M., J.S.D. Munshi, P.K. Roy, N.K Singh, L. Motz and S. Adhikari, 1997. Effects of diazinon on bluegill sunfish, Lepomis macrochirus, gills: scanning electron microscope observations. Exp. Biol. Online 2: 1-11.

Gupta, A., D.K. Rai, R.S. Pandey and B. Sharma, 2009. Analysis of some heavy metals in the riverine water, sediments and fish from river Ganges at Allahabad. Environ. Monitor. Assess., 157: 449-458. 
Manjunatha, B. and G.H. Philip, 2015. Reproductive toxicity of chlorpyrifos tested in zebrafish (Daniorerio): Histological and hormonal end points. J. Toxicol. Ind. Health, 32(10):1808-1816.

Marchand, M.J., J.C. Vandyk, G.M.I. Pieterse, E.J. Barnhoon and M.S. Bornman, 2009.Histopathological alterations in the liver of the Sharptooth catfish Clariasgariepinus from polluted aquatic systems in South Africa, J. Environ. Toxicol., 24: 133-147

Mitra, K., V.R. Suresh, G.K. Vinci, N.N. Mazumdar and D.K.Biswas, 2007.Biology and fishery of banded gourami, Colisafasciata (Bloch and Schneider, 1801) in a floodplain wetland of Ganga river basin. Asian Fish. Sci., 20: 409-423.

Mukti, S.S., G.U. Ahmed, Z.F. Ahmed, K.A. Sumon and M.K. Fatema, 2018. Histopathological study of female striped gourami (Trichogaster fasciata, Bloch \& Schneider, 1801) gill exposed to chlorpyrifos. Int. J. Aqua., 8(14): 104-111.

Narra, M.R., G. Begum, K. Rajender and J.V. Rao, 2011.Sub-lethal effect of chlorpyrifos on protein metabolism of the food fish Clarias batrachus and monitoring of recovery. Toxicol. Environ. Chem.,93: 1650-1658.

Oruce, E.O. and D. Usta, 2007. Evaluation of oxidative stress responses and neurotoxicity potential of diazinon in different tissues of Cyprinus carpio, Environ. Toxicol. ., 23: 48-55

Rani, G.I. and A.K. Kumaraguru, 2014.Behavioural responses and acute toxicity of Clarias batrachusto synthetic pyrethroid insecticide, cyhalothrin. J. Environ. Appl. Biores.,2(1):19-24.

Rao, J.V., G. Begum, V. Sridhar and N.C. Reddy, 2005. Sublethal effects of monocrotophos on locomotor behavior and gill architecture of the mosquito fish, Gambusia affinis. J. Environ. Sci. Health. B.40:813-825.

Reza, W., M.T. Islam, M.H. Uddin, K.A. Sumon and H. Rashid, 2020. Histopathological changes in the internal organs of female striped gourami (Trichogaster fasciata) exposed to sub-lethal concentrations of salt water. Bangladesh J. Fish.,32(2): 237-244.

Rubach, M.N., D.J. Baird, M. Boerwinkel, S.J. Maund, I. Roessink and P.J. Van den Brink, 2012. Species traits as predictors for intrinsic sensitivity of aquatic invertebrates to the insecticide chlorpyrifos. Ecotoxicology, 21: 2088-2101.

Saeedi, F.M., H.V. Roodsari, A. Zamini, E. Mirrasooli and R. Kazemi, 2012. The effects of diazinon on behavior and some hematological parameters of fry rainbow trout (Oncorhynchusmykiss). World J. Fish Mar. Sci., 4(4): 369-375.

Salam, M.A., M. Shahjahan, S. Sharmin, F. Haque and M.K. Rahman, 2015. Effects of sub-lethal doses of an organophosphorous insecticide sumithion on some hematological parameters in common carp, Cyprinus carpio. Pakistan J. Zool., 47(5):1487-1491.

Santhakumar, M., M. Balaji and K. Ramudu, 2001. Gill lesions in the perch, Anabas testudineus, exposed to monocrotophos. J. Environ. Biol., 22: 87-90.

Satyavardhan,K., 2013. A comparative toxicity evaluation and behavioral observations of freshwater fishes to Fenvalerate. Middle-East J. Sci. Res.,13(2):133-136.

Shahjahan, M., M.F. Kabir, K.A Sumon, L.R. Bhowmik and H. Rashid, 2017.Toxicity of organophosphorus pesticide sumithion on larval stages of stinging catfish Heteropneustes fossilis. Chinese J. Oceano. Limnol., 35: 109-114.

Sharmin,S., M. Shahjahan, M.A. Hossain, M.A. Haque and H. Rashid, 2015.Histopathological changes in liver and kidney of common carp exposed to sub-lethal doses of malathion. Pakistan J. Zool., 47(5): 1495-1498.

Sumon K.A., S. Saha, P.J. Van den Brink, E.T.H.M. Peeters, R.H. Bosma and H. Rashid, 2017. Acute toxicity of chlorpyrifos to embryo and larvae of banded gourami Trichogaster fasciata. J. Environ. Sci. Health B,52: 92-98.

Sumon, K.A., A. Rico, M.M.S. Ter Horst, P.J. Van den Brink, M.M.Haque and H. Rashid, 2016. Risk assessment of the pesticides used in rice-prawn concurrent system in Bangladesh. Sci. Total Environ., 568:498-506 
HISTOPATHOLOGICAL ALTERATIONS IN THE GILLS OF T. ASCIATA EXPOSED TO THIAMETHOXAM

Sumon, K.A., M.F. Yesmin, P.J. Van den Brink, R.H. Bosma, E.T.H.M Peeters and H. Rashid, 2019. Effects of long-term chlorpyrifos exposure on mortality and reproductive tissues of Banded Gourami (Trichogaster fasciata).J. Environ. Sci. Health B.,54(7): 549-559.

Ullah, R., A. Zuberi, M.Tariq and S. Ullah, 2014.Toxicity to hematology and morphology of liver, brain and gills during acute exposure of mahseer (Tor putitora) to cypermethrin.Int. J. Agric. Biol.,17(1):199-204.

Van den Brink, P.J., 2013. Assessing aquatic population and community level risks of pesticides. Environ. Toxicol. Chem., 32: 972-973.

(Manuscript received: 30 May 2021) 